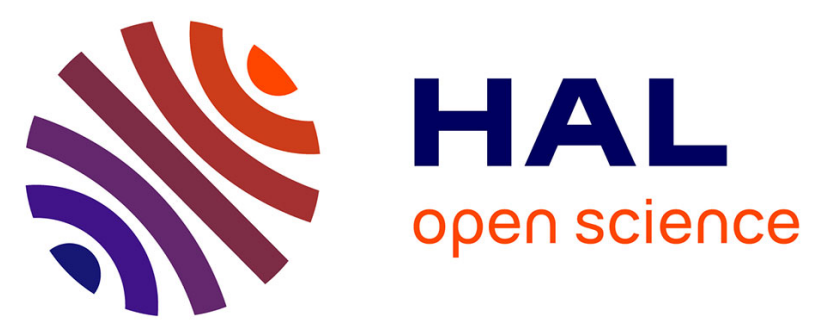

\title{
Characterisation of qnr plasmid-mediated quinolone resistance in Enterobacteriaceae from Italy: association of the qnrB19 allele with the integron element ISCR1 in Escherichia coli
}

Sara N. Richter, Ilaria Frasson, Cristina Bergo, Riccardo Manganelli, Antonietta Cavallaro, Giorgio Palù

\section{To cite this version:}

Sara N. Richter, Ilaria Frasson, Cristina Bergo, Riccardo Manganelli, Antonietta Cavallaro, et al.. Characterisation of qnr plasmid-mediated quinolone resistance in Enterobacteriaceae from Italy: association of the qnrB19 allele with the integron element ISCR1 in Escherichia coli. International Journal of Antimicrobial Agents, 2010, 35 (6), pp.578. 10.1016/j.ijantimicag.2010.02.015 . hal-00585826

\author{
HAL Id: hal-00585826 \\ https://hal.science/hal-00585826
}

Submitted on 14 Apr 2011

HAL is a multi-disciplinary open access archive for the deposit and dissemination of scientific research documents, whether they are published or not. The documents may come from teaching and research institutions in France or abroad, or from public or private research centers.
L'archive ouverte pluridisciplinaire HAL, est destinée au dépôt et à la diffusion de documents scientifiques de niveau recherche, publiés ou non, émanant des établissements d'enseignement et de recherche français ou étrangers, des laboratoires publics ou privés. 


\section{Accepted Manuscript}

Title: Characterisation of qnr plasmid-mediated quinolone resistance in Enterobacteriaceae from Italy: association of the qnrB19 allele with the integron element ISCR1 in Escherichia coli

Authors: Sara N. Richter, Ilaria Frasson, Cristina Bergo,

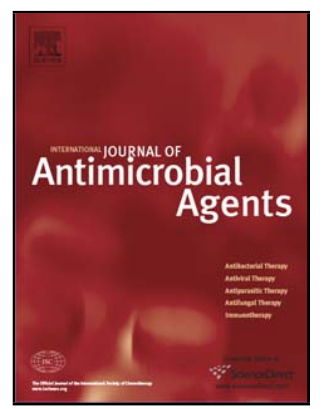

Riccardo Manganelli, Antonietta Cavallaro, Giorgio Palù

PII:

S0924-8579(10)00089-0

DOI: doi:10.1016/j.ijantimicag.2010.02.015

Reference: ANTAGE 3265

To appear in: International Journal of Antimicrobial Agents

Received date: $\quad 14-1-2010$

Revised date: $\quad 3-2-2010$

Accepted date: $\quad 10-2-2010$

Please cite this article as: Richter SN, Frasson I, Bergo C, Manganelli R, Cavallaro $\mathrm{A}$, Palù $\mathrm{G}$, Characterisation of qnr plasmid-mediated quinolone resistance in Enterobacteriaceae from Italy: association of the qnrB19 allele with the integron element ISCR1 in Escherichia coli, International Journal of Antimicrobial Agents (2008), doi:10.1016/j.ijantimicag.2010.02.015

This is a PDF file of an unedited manuscript that has been accepted for publication. As a service to our customers we are providing this early version of the manuscript. The manuscript will undergo copyediting, typesetting, and review of the resulting proof before it is published in its final form. Please note that during the production process errors may be discovered which could affect the content, and all legal disclaimers that apply to the journal pertain. 


\section{Characterisation of qnr plasmid-mediated quinolone resistance in Enterobacteriaceae from Italy: association of the qnrB19 allele with the integron element ISCR1 in Escherichia coli}

Sara N. Richter ${ }^{a, b, *}$, Ilaria Frasson ${ }^{a}$, Cristina Bergo ${ }^{b}$, Riccardo Manganelli a,b, Antonietta Cavallaro ${ }^{b}$, Giorgio Palù ${ }^{a, b}$

a Department of Histology, Microbiology and Medical Biotechnologies, University of Padua, via Gabelli 63, 35121 Padua, Italy

${ }^{\mathrm{b}}$ Azienda Ospedaliera of Padua, Microbiology and Virology Unit, via Giustiniani 2, 35121 Padua, Italy

\section{ARTICLE INFO}

Article history:

Received 14 January 2010

Accepted 10 February 2010

Keywords:

Fluoroquinolones

Plasmid-mediated resistance

Gram-negative

* Corresponding author. Tel.: +39 049827 2346; fax: +39 0498272355.

E-mail address: sara.richter@unipd.it (S.N. Richter). 


\section{ABSTRACT}

The spread of plasmid-mediated quinolone resistance determinants (qnr-like determinants) was evaluated in a collection of 232 ciprofloxacin-resistant or extended-spectrum $\beta$-lactamase (ESBL)-producing enterobacterial isolates recovered between November 2007 and May 2008 at Padua University Hospital, Italy. qnr genes were mainly found in Klebsiella pneumoniae (68\%) and to a lesser extent in Escherichia coli (5.1\%). Among the qnrA1, qnrS1 and qnrB19 alleles found, the latter was by far the most frequent. Genetic environment analysis revealed that one qnrB19 gene in E. coli was embedded in an ISCR1 complex class 1 integron. All other qnrB19 genes were flanked by an ISEcp1C region as part of the Tn2012 transposon. qnrA1-and qnrS1-containing strains were not clonally related. Both topoisomerase II mutations and ESBL (mainly SHV-12, TEM-1 and TEM-150 types) were present in most of the qnr-positive strains. qnrB19 is extremely frequent in K. pneumoniae isolates from Italy. In addition, association of $q n r B 19$ with the ISCR1 mobile element in E. coli suggests a broad distribution of this resistance gene in the near future. 


\section{Introduction}

Fluoroquinolones are among the most commonly prescribed antimicrobials because of their broad-spectrum antimicrobial activity. However, this intense usage of fluoroquinolones has boosted the emergence of resistance worldwide, especially in Gram-negative bacterial species. Classic quinolone resistance in Enterobacteriaceae is mediated by chromosomally encoded point mutations in the quinolone resistance-determining regions (QRDRs) of the DNA gyrase and topoisomerase IV genes or by mutation of genes regulating the expression of efflux pumps [1]. More recently, plasmid-mediated quinolone resistance has been reported, with three known mechanisms to date: gyrase and topoisomerase IV protection encoded by the qnr genes [2,3]; enzymatic drug detoxification encoded by aac $\left(6^{\prime}\right)-I b-\operatorname{cr}[4]$; and specific efflux mediated by the qepA product [5]. The latter two mechanisms affect only fluoroquinolones with specific features (i.e. hydrophilicity and free piperazinyl amine, e.g. ciprofloxacin and norfloxacin) and hence treatment with other compounds of the same antimicrobial class (e.g. levofloxacin and ofloxacin) remains an option. In contrast, qnrmediated resistance is effective against all fluoroquinolones and hence requires treatment shift to a different class of antimicrobials. The observation that $q n r$ is often found in association with genes that confer resistance to other classes of antibiotics [6] (e.g. $\beta$-lactams and aminoglycosides) implies that Enterobacteriaceae strains presenting qnr resistance may represents a serious concern in the clinical environment.

Three major groups of Qnr determinants have been described (QnrA, QnrB and QnrS), which share between $40 \%$ and $60 \%$ similarity [3]. More recently, two other groups have been described, qnrC [7] and qnrD [8]. 
In this paper, the dissemination of qnr plasmid-mediated quinolone resistance was assayed among clinical Enterobacteriaceae isolates from Italy. gnr genes were found mainly in Klebsiella pneumoniae and to a lesser extent in Escherichia coli. Among the qnrA1, qnrS1 and qnrB19 alleles found, the latter was by far the most frequent. Genetic environment analysis revealed that one qnrB19 gene was embedded in an ISCR1 complex class 1 integron, whilst all other qnrB19 genes were flanked by an ISEcp1C region as part of the Tn2012 transposon.

\section{Materials and methods}

\subsection{Sample selection}

In total, 232 non-duplicate clinical isolates recovered between November 2007 and May 2008 at Padua University Hospital (Italy) were selected on the basis of ciprofloxacin resistance [minimum inhibitory concentration (MIC) $\geq 0.25 \mu \mathrm{g} / \mathrm{mL}$ ] or extended-spectrum $\beta$-lactamase (ESBL) production. In addition, ten samples fully susceptible to ciprofloxacin (MIC $<0.25$ $\mu \mathrm{g} / \mathrm{mL}$ ) and lacking ESBL production were also included in the study. Bacterial isolates included 157 E. coli, 47 K. pneumoniae, 2 Klebsiella oxytoca, 12 Proteus mirabilis, 5 Enterobacter aerogenes, 4 Enterobacter cloacae, 4 Citrobacter freundii and 1 Citrobacter koseri. Sample origin was mostly urine (175 samples); the remaining were from the respiratory tract (17), blood (11), skin/wounds (14), stools (2), pus/viscera (10) and the urogenital tract (3). Of samples were collected, $92 \%$ were from inpatients. Patients were equally distributed between females (48\%) and males (52\%). 


\subsection{Antimicrobial susceptibility testing}

Exact MIC values were determined by the disk diffusion test according to Clinical and Laboratory Standards Institute (CLSI) methods [9] and were confirmed by means of Etest strips (AB BIODISK, Solna, Sweden). ESBL production was detected according to CLSI guidelines M2-A9 and M100-S19 [9,10].

\subsection{Polymerase chain reaction (PCR) amplification and DNA sequencing}

Screening of $q n r A, q n r B$ and $q n r S$ genes was carried out by multiplex PCR amplification [11]. qnrC and $q n r D$ genes were not included in this study as they were not known when the study was planned. Positive controls were represented by DNA of known qnr-positive strains: $E$. cloacae HM04-477 (qnrA1) [12]; E. cloacae HM05-186 (qnrB4) [13]; and E. coli HM5-184 (qnrS1) [14].

Primers for detection of aac(6')-Ib and qepA were: aacF, 5'-ATGACTGAGCATGACCTTG-3'; aacR, 5'-AACCATGTACACGGCTGG-3'; qepAF, 5'-TGGTCTACGCCATGGACCTCA-3'; and qepAR, 5'-TGAATTCGGACACCGTCTCCG-3'.

The presence of $\beta$-lactamases genes (ESBLs blasHV, bla $a_{\text {TEM }}$, bla $a_{\mathrm{CTX}-\mathrm{M}-1}$, bla $a_{\mathrm{CTX}-\mathrm{M}-2}$, bla $a_{\mathrm{CTX}-\mathrm{M}-8}$ and bla $a_{\mathrm{CTX}-\mathrm{M}-9}$ and AmpC enzymes blamox-1, blamoX-2, bla $a_{\mathrm{CMY}-1-11}$, bla $a_{\mathrm{LAT}-1-4}, b / a_{\mathrm{BIL}-1}$, bla $a_{\mathrm{DHA}-1}$, bla $a_{\mathrm{DHA}-2}, b / a_{\mathrm{ACC}}, b / a_{\mathrm{MIR}-1 \mathrm{~T}}, b / a_{\mathrm{ACT}-1}$, and b/a $\left.a_{\mathrm{FOX}-1-5 b}\right)$ was assessed on the qnr-positive isolates using specific primers [15-18]. 
PCR amplification and sequencing of the QRDR of $g y r A$ and parC genes was performed using universal primers [19].

Primers for sequencing the genetic environment of qnrB19 genes were specific for the ISEcp1 insertion sequence or 5'-conserved sequence (5'CS) (prF ISEcp1, 5'CGACATGGCGGTGGGTCATC-3'; prR ISEcp1, 5'-CTGCTTGTCACACATTGTAAC-3'; and pr5'CS, 5'-GGCATCCAAGCAGCAAG-3' [20]) or were specific and outward facing for the qnrB19 gene (pr5'qnrB19, 5'-GCGAGTCCAGCCGTGGAC-3'; and pr3'qnrB19comp, 5'CCGCAATTCAATCTGTCGATGG-3').

Positive results were confirmed by direct sequencing of PCR products.

\subsection{Plasmids isolation and analysis}

Plasmids from qnr-positive bacterial isolates were purified according to the Kieser protocol [21]. Purified plasmids were run on a $0.7 \% \mathrm{Mb}$ agarose gels at $4{ }^{\circ} \mathrm{C}$ for $5 \mathrm{~h}$ at $4.5 \mathrm{~V} / \mathrm{cm}$ and were stained with ethidium bromide.

\subsection{Conjugation and transformation}

Conjugation experiments were performed by a filter mating assay using a kanamycin-resistant E. coli $553^{\mathrm{AzR}}$ strain as the recipient and selecting on Luria-Bertani (LB) agar supplemented with $100 \mu \mathrm{g} / \mathrm{mL}$ sodium azide, $50 \mu \mathrm{g} / \mathrm{mL}$ kanamycin and $30 \mu \mathrm{g} / \mathrm{mL}$ nalidixic acid. 
For transformation experiments, plasmids purified and separated on agarose gels were electroporated into E. coli TOP10 (Invitrogen Ltd., Paisley, UK) using a Bio-Rad Gene Pulser ${ }^{\circledR}$ (Bio-Rad Laboratories, Milan, Italy). Transformants were selected on LB agar supplemented with $30 \mu \mathrm{g} / \mathrm{mL}$ nalidixic acid.

\subsection{Molecular typing}

The clonal relationship among strains was assessed based on the repetitive element PCR fingerprinting method, using the 'enterobacterial repetitive intergenic consensus' (ERIC) primers ERIC1 and ERIC2 [15].

\section{Results}

\subsection{Phenotypic characterisation of isolates}

qnr genes were detected in $40(17 \%)$ of 232 unique clinical isolates of Enterobacteriaceae collected from Padua University Hospital between November 2007 and May 2008 (Table 1), comprising $32(68 \%)$ of 47 K. pneumoniae and 8 (5.1\%) of 157 E. coli. In particular, qnrA and qnrB were detected in $1(2.1 \%)$ and $31(66 \%)$ of $47 \mathrm{~K}$. pneumoniae isolates, respectively, and qnrB and qnrS were detected in 5 (3.2\%) and 3 (1.9\%) of 157 E. coli isolates, respectively. No qnr gene was identified in other bacterial species and no isolate carried more than one qnr gene. All qnrB genes were identified as qnrB19 alleles [22] by sequencing; qnrA and qnrS genes were identified as $q n r A 1$ and $q n r S 1$, respectively. The genes aac(6')-Ib-cr and qepA were absent in all strains with the exception of five qnrB19-positive isolates that harboured aac(6')-Ib (samples \#111, \#137, \#143, \#144 and \#176; Table 1). 
Among the 40 qnr-positive isolates, $31 / 40$ (78\%), 3/40 (7.5\%), 5/40 (13\%), 3/28 (11\%) and $3 / 40(7.5 \%)$ isolates were nalidixic acid-, ciprofloxacin-, ofloxacin-, levofloxacin- and moxifloxacin-resistant, respectively, according to CLSI criteria (Table 2). However, when considering European Committee on Antimicrobial Susceptibility Testing (EUCAST) breakpoints, the isolates were in general more resistant to fluoroquinolones $(82 \%, 37 \%, 92 \%$, $18 \%$ and $82 \%$, respectively).

\subsection{Mutations conferring quinolone resistance}

Twenty-eight isolates were identified with a D87G GyrA mutation, one isolate with two point mutations in GyrA (S83L and D87N) and one mutation in ParC (S80I) (\#9), and one isolate with S83I and S80I mutations in GyrA and ParC, respectively (\#70). It is interesting to note that these latter two isolates were the only qnr-positive strains resistant to all tested fluoroquinolones. On the other hand, strains showing no mutation at the topoisomerase II level (i.e. the three qnrS1-positive E. coli strains \#114, \#191 and \# 282 and the qnrB19positive E. coli \#47, \#50, \#60 and \#132 and K. pneumoniae \#97, \#204 and \#229) were susceptible to all tested fluoroquinolones as well as to nalidixic acid.

\subsection{Association between qnr and extended-spectrum $\beta$-lactamase}

Since qnr genes have been associated with plasmid-mediated $\beta$-lactamases [23], the presence of $\beta$-lactamases was assessed. In total, 30 of 40 samples contained bla genes (association of up to three different types was found in single isolates) (Table 1). Conversely, no sample carried plasmid-mediated AmpC $\beta$-lactamases. ESBL production was also 
analysed phenotypically. On the whole, a clear association was found between qnr genes and ESBLs: whilst $33 \%$ of the initial 232 clinical isolates tested were ESBL-producers, this value increased to $72 \%$ (ESBL phenotypic testing) and 75\% (ESBL genotypic analysis) in qnrpositive samples.

Finally, qnr-positive isolates remained mostly susceptible to amikacin $(80 \%)$, gentamicin (85\%), tetracycline (86\%), trimethoprim/sulfamethoxazole (90\%) and imipenem (100\%), indicating no significant increase in resistance to aminoglycosides, tetracyclines, cotrimoxazole or carbapenems associated with qnr genes. The qnrA1-positive sample was the only isolate displaying simultaneous resistance to aminoglycosides, tetracyclines and cotrimoxazole; in addition, qnrS1-positive E. coli isolate \#282 was resistant to tetracyclines and co-trimoxazole (data not shown).

\subsection{Characterisation of the genetic environment of qnr}

Analysing the plasmid electrophoretic profiles of qnr-positive isolates, all qnrB19-positive isolates showed identical profiles, with the exception of qnrB19-positive E. coli isolate \#132. The plasmid pattern of $q n r A 1$ - and $q n r S 1$-positive isolates was similar, but differed from both qnrB19 patterns (Fig. 1).

To determine whether the qnr determinants were plasmid-encoded, qnr-containing electrophoretic bands from seven arbitrarily chosen samples (one qnrA1-, four qnrB19- and two qnrS1-positive samples) were successfully transformed into E. coli TOP10 electrocompetent cells, indicating a plasmid location for all tested qnr genes. The qnrcontaining plasmid size in each case was $>23 \mathrm{~Kb}$. MICs of different fluoroquinolone drugs 
against transformant strains were measured and were compared with those of the acceptor strain (i.e. E. coli TOP10). The MICs of ciprofloxacin and levofloxacin increased 27-80-fold and $80-115$-fold, respectively, in the qnr-transformed strains. The MIC of nalidixic acid was the most variable, increasing from 16 -fold to 128 -fold in the transformant strains. When comparing transformant versus parent strains, MICs of the transformant strains decreased by at least 40 -fold or $1-3$-fold when the MIC of the parent strain was $>1 \mu \mathrm{g} / \mathrm{mL}$ (i.e. strains \#70, $\# 71, \# 111$ and \#146) or $<1 \mu \mathrm{g} / \mathrm{mL}$ (strains \#132, \#191 and \#282), respectively (Table 1). In addition, bla genes were never co-transformed with qnr, indicating a different genetic location.

To determine whether the qnr-harbouring plasmid was conjugative, two qnr-positive E. coli isolates [\#132 (qnrB19) and \#191 (qnrS1)] were successfully used as donors in conjugation experiments. The MICs of ciprofloxacin, levofloxacin and nalidixic acid in the transconjugant strains were 14-20-, 7- and 5-10-fold higher, respectively, than those of the wild-type recipient, and 1-2-fold lower compared with those in the donor strains. Both transformed strains and transconjugants displayed no mutation at the gyrA and parC level.

The environment surrounding the qnrB19 genes was first investigated using primers complementary to the ISEcp1C region of transposon Tn2012, previously reported to be associated with the qnrB19 gene [22]. Of 36 qnrB19-positive samples, 35 contained the ISEcp 1C transposase at the 3' end of the qnrB19 gene. Sequence analysis confirmed that these qnrB19 genes were all part of the Tn2012 transposon, with the qnrB19 gene followed by the ISEcp $1 C$ element. Interestingly, these 35 isolates reported the exact same plasmid electrophoretic profile (see Fig. 1). 
To assess the genetic environment of the remaining qnrB19-positive E. coli strain (\#132), plasmid DNA was purified and subjected to direct sequencing. Analysis of a $1.3 \mathrm{~kb} q \mathrm{nr}-$ containing DNA region indicated that the qnrB19 gene was embedded in an ISCR1-containing mobile element integron complex class I. The integron was flanked by the $5^{\prime} \mathrm{CS}$ followed by the inverted repeat region 2 (IRR2). A truncated $p s p$ operon was immediately upstream of the qnrB19 gene. Downstream, an Int1 element with its putative recombination site was present, followed by the sapA gene disrupted by recombination events and a second recombination site (GenBank accession no. GU074393) (Fig. 2).

\subsection{Clonal relationships among isolates}

Finally, the clonal relationship among the isolates in this study was assessed by studying the ERIC-PCR genomic DNA profiles. As shown in Table 1, qnrB19-positive samples were grouped in seven clonally related subgroups. In addition, 17 (47\%) and 8 (22\%) of 36 qnrB19positive isolates belong to the same two most numerous subgroups, respectively. However, the three qnrS1-positive isolates were all clonally unrelated.

\section{Discussion}

In this work, we have detected for the first time the presence of qnr genes that confer mild resistance to quinolones among enterobacterial isolates collected in the Northeast region of Italy.

Interestingly, all qnrB-positive K. pneumoniae as well as some E. coli strains bore the qnrB19 allele. Of these, all but one were embedded within a transposon Tn2012 structure associated 
with an ISEcp1 element and reported identical plasmid electrophoretic profiles. Tn2012 was reported for the first time in an E. coli clinical isolate from Colombia in 2008 [22]. Recently, qnrB19 genes were reported in Salmonella strains from The Netherlands [24] and Italy [25]; all of them were transposon-associated.

In one of our analysed isolates, qnrB19 was found in a completely different context. Genetic environment analysis revealed its association with an integron complex class I bearing an ISCR1 mobile element. This is the first time a qnrB19 gene has been reported in an ISCR1 integron environment, whilst other qnr alleles have been previously described associated with this genetic element (i.e. qnrA1, qnrB2, qnrB6 and qnrB10) $[19,20,26-28]$. Very recently, experimental data provided a likely mechanism for ISCR1-mediated qnrB2 gene mobilisation [29]. ISCR1 can transpose adjacent DNA sequences, mediated by a single copy of the element, in contrast to ISEcp1 where two copies of the element are needed to flank the mobilised gene. In addition, the ISCR1 element plays a role in the expression of nearby genes by providing a promoter [30]. Hence, ISCR1 may be responsible for the mobilisation of virtually any DNA in an extremely efficient manner, and resistance genes found in ISCR1 gene cassettes are potentially highly mobile [31]. The fact that only one isolate was found with qnrB19 in this genetic background and that it did not present any further mutation increasing resistance to fluoroquinolones (i.e. topoisomerase II mutations) or to other classes of antibiotics (i.e. ESBL) indicates the rather recent acquisition of the qnrB19 gene in this strain. The intrinsic properties of its genetic environment predict a high diffusion of this qnrB19 embedded in an ISCR1-bearing mobile element and therefore we expect to find increased qnrB19-mediated resistance to fluoroquinolones in the near future. 
In contrast, ISEcp1 qrrB19 genes were probably acquired some time ago, since most of them displayed concurrent types of resistance mechanisms such as topoisomerase II mutations, high-level resistance to fluoroquinolones and intensive ESBL production, which are usually stimulated by and then become associated with the qnr gene [3]. It is possible that these ISEcp1 qnrB19 genes were initially acquired from a single source in the initial location (i.e. Colombia where they were first reported [22]) through strain exchange by travellers and patients between South America and Europe. However, this gene now appears uniformly diffuse in our region since qnrB19-positive samples were collected both from inpatients and outpatients and were randomly distributed among different hospital units.

By contrast, non-qnrB19 genes were found both in K. pneumoniae (qnrA1) and E. coli (qnrS1) isolates. Both their phenotypic and genetic profiles indicated that they were more diversified and were likely acquired from diverse sources.

On the whole, K. pneumoniae species were more likely to present qnr genes than E. coli isolates ( $68 \%$ and $5 \%$ of the initial K. pneumoniae and E. coli isolates, respectively). To our knowledge, this is one of the widest spreading of qnr genes in K. pneumoniae isolates. In addition, no similar distribution for the qnrB19 gene has ever been reported. Generally, $q n r$ genes are largely associated with ESBLs: the prevalence of bla genes increased from $33 \%$ in all tested isolates to $75 \%$ in qnr-positive strains. Nevertheless, contrary to most samples reported in the literature $[3,6,22]$, qnr and bla genes did not co-localise on the same plasmid. qnr-positive samples were mainly resistant to nalidixic acid and susceptible to other types of antibiotics. Resistance to nalidixic acid and the presence of ESBLs are two phenotypically measured properties that possibly indicate the presence of plasmid-mediated mechanisms of 
resistance to fluoroquinolones. However, in our experience these two features did not make a predictive phenotype, since six of ten nalidixic acid-susceptible and ESBL-negative samples were qnr-positive. Hence, it would be interesting to analyse next the dissemination of plasmidmediated resistance mechanisms on a larger set of 'susceptible' clinical isolates.

\section{Acknowledgments}

The authors thank Prof. E. Cambau (University of Paris XII, France) for kindly donating qnrpositive control strains; Prof. L. Martínez-Martínez (University Hospital Marqués de Valdecilla, Santander, Spain) for the gift of E. coli J53 ${ }^{\mathrm{AzR}}$; and Prof. L. Poirel (Université Paris-Sud, France) for generously sharing his Kieser protocol.

\section{Funding}

This work was supported by Ministero dell'Istruzione, dell'Università e della Ricerca (MIUR) (grant FIRB-Ideas RBID082ATK).

\section{Competing interests}

None declared.

\section{Ethical approval}

Not required. 


\section{References}

[1] Hooper DC. Mechanisms of action and resistance of older and newer fluoroquinolones. Clin Infect Dis 2000;31(Suppl 2):S24-8.

[2] Tran JH, Jacoby GA. Mechanism of plasmid-mediated quinolone resistance. Proc Natl Acad Sci U S A 2002;99:5638-42.

[3] Strahilevitz J, Jacoby GA, Hooper DC, Robicsek A. Plasmid-mediated quinolone resistance: a multifaceted threat. Clin Microbiol Rev 2009;22:664-89.

[4] Robicsek A, Strahilevitz J, Jacoby GA, Macielag M, Abbanat D, Park CH, et al. Fluoroquinolone-modifying enzyme: a new adaptation of a common aminoglycoside acetyltransferase. Nat Med 2006;12:83-8.

[5] Perichon B, Courvalin P, Galimand M. Transferable resistance to aminoglycosides by methylation of G1405 in 16S rRNA and to hydrophilic fluoroquinolones by QepA-mediated efflux in Escherichia coli. Antimicrob Agents Chemother 2007;51:2464-9.

[6] Robicsek A, Jacoby GA, Hooper DC. The worldwide emergence of plasmid-mediated quinolone resistance. Lancet Infect Dis 2006;6:629-40.

[7] Wang M, Guo Q, Xu X, Wang X, Ye X, Wu S, et al. New plasmid-mediated quinolone resistance gene, $q n r C$, found in a clinical isolate of Proteus mirabilis. Antimicrob Agents Chemother 2009;53:1892-7.

[8] Cavaco LM, Hasman H, Xia S, Aarestrup FM. qnrD, a novel gene conferring transferable quinolone resistance in Salmonella enterica serovar Kentucky and Bovismorbificans strains of human origin. Antimicrob Agents Chemother 2009;53:603-8.

[9] Clinical and Laboratory Standards Institute. Performance standards for antimicrobial disk susceptibility tests; approved standard. 9th ed. Document M2-A9. Wayne, PA: CLSI; 2006. 
[10] Clinical and Laboratory Standards Institute. Performance standards for antimicrobial susceptibility testing. Nineteenth informational supplement. Document M100-S19. Wayne, PA: CLSI; 2009.

[11] Cattoir V, Poirel L, Rotimi V, Soussy CJ, Nordmann P. Multiplex PCR for detection of plasmid-mediated quinolone resistance qnr genes in ESBL-producing enterobacterial isolates. J Antimicrob Chemother 2007;60:394-7.

[12] Cambau E, Lascols C, Sougakoff W, Bebear C, Bonnet R, Cavallo JD, et al. Occurrence of qnrA-positive clinical isolates in French teaching hospitals during 20022005. Clin Microbiol Infect 2006;12:1013-20.

[13] Merens A, Matrat S, Aubry A, Lascols C, Jarlier V, Soussy CJ, et al. The pentapeptide repeat proteins MfpAMt and QnrB4 exhibit opposite effects on DNA gyrase catalytic reactions and on the ternary gyrase-DNA-quinolone complex. J Bacteriol 2009;191:158794.

[14] Cesaro A, Bettoni RR, Lascols C, Merens A, Soussy CJ, Cambau E. Low selection of topoisomerase mutants from strains of Escherichia coli harbouring plasmid-borne qnr genes. J Antimicrob Chemother 2008;61:1007-15.

[15] Lavilla S, Gonzalez-Lopez JJ, Sabate M, Garcia-Fernandez A, Larrosa MN, Bartolome $\mathrm{RM}$, et al. Prevalence of qnr genes among extended-spectrum $\beta$-lactamase-producing enterobacterial isolates in Barcelona, Spain. J Antimicrob Chemother 2008;61:291-5.

[16] Li H, Li JB. Detection of five novel CTX-M-type extended spectrum $\beta$-lactamases with one to three CTX-M-14 point mutations in isolates from Hefei, Anhui province, China. J Clin Microbiol 2005;43:4301-2.

[17] Perez-Perez FJ, Hanson ND. Detection of plasmid-mediated AmpC $\beta$-lactamase genes in clinical isolates by using multiplex PCR. J Clin Microbiol 2002;40:2153-62. 
[18] Villegas MV, Correa A, Perez F, Zuluaga T, Radice M, Gutkind G, et al. CTX-M-12 $\beta$ lactamase in a Klebsiella pneumoniae clinical isolate in Colombia. Antimicrob Agents Chemother 2004;48:629-31.

[19] Lascols C, Robert J, Cattoir V, Bebear C, Cavallo JD, Podglajen I, et al. Type II topoisomerase mutations in clinical isolates of Enterobacter cloacae and other enterobacterial species harbouring the qnrA gene. Int J Antimicrob Agents 2007;29:402-9.

[20] Quiroga MP, Andres P, Petroni A, Soler Bistue AJ, Guerriero L, Vargas LJ, et al. Complex class 1 integrons with diverse variable regions, including aac(6')-lb-cr, and a novel allele, qnrB10, associated with ISCR1 in clinical enterobacterial isolates from Argentina. Antimicrob Agents Chemother 2007;51:4466-70.

[21] Kieser T. Factors affecting the isolation of CCC DNA from Streptomyces lividans and Escherichia coli. Plasmid 1984;12:19-36.

[22] Cattoir V, Nordmann P, Silva-Sanchez J, Espinal P, Poirel L. ISEcp1-mediated transposition of qnrB-like gene in Escherichia coli. Antimicrob Agents Chemother 2008;52:2929-32.

[23] Nordmann P, Poirel L. Emergence of plasmid-mediated resistance to quinolones in Enterobacteriaceae. J Antimicrob Chemother 2005;56:463-9.

[24] Garcia-Fernandez A, Fortini D, Veldman K, Mevius D, Carattoli A. Characterization of plasmids harbouring qnrS1, qnrB2 and qnrB19 genes in Salmonella. J Antimicrob Chemother 2009;63:274-81.

[25] Dionisi AM, Lucarelli C, Owczarek S, Luzzi I, Villa L. Characterization of the plasmidborne quinolone resistance gene qnrB19 in Salmonella enterica serovar Typhimurium. Antimicrob Agents Chemother 2009;53:4019-21. 
[26] Castanheira M, Pereira AS, Nicoletti AG, Pignatari AC, Barth AL, Gales AC. First report of plasmid-mediated qnrA1 in a ciprofloxacin-resistant Escherichia coli strain in Latin America. Antimicrob Agents Chemother 2007;51:1527-9.

[27] Ode T, Saito R, Kumita W, Sato K, Okugawa S, Moriya K, et al. Analysis of plasmidmediated multidrug resistance in Escherichia coli and Klebsiella oxytoca isolates from clinical specimens in Japan. Int J Antimicrob Agents 2009;34:347-50.

[28] Ma J, Zeng Z, Chen Z, Xu X, Wang X, Deng Y, et al. High prevalence of plasmidmediated quinolone resistance determinants $q n r$, aac $\left(6^{\prime}\right)-I b-c r$, and $q e p A$ among ceftiofurresistant Enterobacteriaceae isolates from companion and food-producing animals. Antimicrob Agents Chemother 2009;53:519-24.

[29] Chen YT, Liao TL, Liu YM, Lauderdale TL, Yan JJ, Tsai SF. Mobilization of qnrB2 and ISCR1 in plasmids. Antimicrob Agents Chemother 2009;53:1235-7.

[30] Rodriguez-Martinez JM, Poirel L, Canton R, Nordmann P. Common region CR1 for expression of antibiotic resistance genes. Antimicrob Agents Chemother 2006;50:2544-6.

[31] Toleman MA, Bennett PM, Walsh TR. ISCR elements: novel gene-capturing systems of the 21st century? Microbiol Mol Biol Rev 2006;70:296-316. 
Fig. 1. Plasmid electrophoretic profiles of qnr-positive samples. M, molecular weight marker. Samples are indicated according to their ID number (ID \#) and their qnr allele ( $B$ stands for qnrB19 and S for qnrS1).

Fig. 2. Genetic environment flanking the qnrB19 gene in isolate \#132. The qnrB19 gene is embedded in an ISCR1-type mobile element integron complex class I (In1:ISCR1:QnrB19). The integron is flanked on one side by the $5^{\prime}$-conserved sequence $\left(5^{\prime} \mathrm{CS}\right)$ followed by the inverted repeat region 2 (IRR2). The psp operon transcriptional activator ( $p s p$ O-TA) is truncated and immediately upstream of the qnrB19 gene. Downstream, an integrase 1 (int1) with its putative recombination site is present, followed by the sapA (a peptide transport system permease) gene disrupted by recombination events and a second recombination site (GenBank accession no. GU074393). 


\section{Table 1}

Properties of qnr-positive clinical isolates and transformant and transconjugant strains

\begin{tabular}{|c|c|c|c|c|c|c|c|c|c|c|c|c|c|}
\hline Sampl & Bacterial & $q n r$ & $\operatorname{aac}\left(6^{\prime}\right)$ & $\mathrm{MIC}$ & $\mathrm{ng} / \mathrm{L})$ & & &  & GyrA & Par & $\mathrm{ESBL}^{\mathrm{a}}$ & & ERIC \\
\hline e ID & species & gene & $\begin{array}{l}-l b \\
\text { gene }\end{array}$ & NA & CIP & OFX & LVF & MXF & & C & $\begin{array}{l}\text { Phenotypi } \\
\text { c }\end{array}$ & $\begin{array}{l}\text { Genotypi } \\
\text { c }\end{array}$ & -PCR \\
\hline 5 & $\begin{array}{l}\text { Klebsiella } \\
\text { pneumoni } \\
\text { ae }\end{array}$ & $\begin{array}{l}\text { qnrB1 } \\
9\end{array}$ & & $\begin{array}{c}>25 \\
6\end{array}$ & 1 & 4 & 1.5 & 1.5 & $\begin{array}{c}\mathrm{D} 87 \\
\mathrm{G}\end{array}$ & - & $X$ & & B2 \\
\hline 9 & $\begin{array}{l}\text { Escherichia } \\
\text { coli }\end{array}$ & $\begin{array}{l}\text { qnrB1 } \\
9\end{array}$ & & $\begin{array}{c}>25 \\
6\end{array}$ & $>32$ & $>32$ & $>32$ & $>32$ & $\begin{array}{l}\text { S83L } \\
\text { D87 } \\
\mathrm{N}\end{array}$ & S80I & $x$ & $\begin{array}{l}\text { TEM-1 + } \\
\text { SHV-12 }\end{array}$ & B7 \\
\hline 16 & $\begin{array}{l}\text { K. } \\
\text { pneumoni } \\
\text { ae }\end{array}$ & $\begin{array}{l}\text { qnrB1 } \\
9\end{array}$ & & $\begin{array}{c}>25 \\
6\end{array}$ & 1.5 & 6 & 2 & 2 & $\begin{array}{c}D 87 \\
G\end{array}$ & - & $X$ & $\begin{array}{l}\text { TEM-150 } \\
+ \text { SHV- } \\
12\end{array}$ & B2 \\
\hline 47 & E. coli & $\begin{array}{l}\text { qnrB1 } \\
9\end{array}$ & & 4 & $\begin{array}{c}0.12 \\
5\end{array}$ & 1 & $N / D$ & 0.38 & - & - & $X$ & TEM-1 & B7 \\
\hline 50 & E. coli & $\begin{array}{l}\text { qnrB1 } \\
9\end{array}$ & & 8 & 0.19 & 0.75 & $N / D$ & 0.5 & - & - & $x$ & SHV-12 & B6 \\
\hline 60 & E. coli & $\begin{array}{l}\text { qnrB1 } \\
9\end{array}$ & & 6 & $\begin{array}{c}0.12 \\
5\end{array}$ & 2 & $N / D$ & 0.38 & - & - & $x$ & TEM-1 & B7 \\
\hline
\end{tabular}




\begin{tabular}{|c|c|c|c|c|c|c|c|c|c|c|c|c|}
\hline 70 & $K$ & qnrA1 & $>25$ & $>32$ & $>32$ & $>32$ & $>32$ & S83I & S80I & $X$ & TEM-1 + & A1 \\
\hline & pneumoni & & 6 & & & & & & & & SHV-12 & \\
\hline & $a e$ & & & & & & & & & & + CTX- & \\
\hline & & & & & & & & & & & M-1 & \\
\hline $70 T$ & E. coli & qnrA1 & 48 & 0.01 & $N / D$ & $\mathrm{~N} / \mathrm{D}$ & $N / D$ & - & - & & & \\
\hline & TOP10 & & & 6 & & & & & & & & \\
\hline 71 & $K$ & $q n r B 1$ & $>25$ & 1.5 & 8 & $\mathrm{~N} / \mathrm{D}$ & 2 & D87 & - & & & B5 \\
\hline & pneumoni & 9 & 6 & & & & & G & & & & \\
\hline & $a e$ & & & & & & & & & & & \\
\hline $71 \mathrm{~T}$ & E. coli & qnrB1 & 64 & 0.02 & $\mathrm{~N} / \mathrm{D}$ & $\mathrm{N} / \mathrm{D}$ & $\mathrm{N} / \mathrm{D}$ & - & - & & & \\
\hline & TOP10 & 9 & & 3 & & & & & & & & \\
\hline 97 & $K$ & $q n r B 1$ & 16 & 0.75 & 3 & $\mathrm{~N} / \mathrm{D}$ & 1.5 & - & - & & & B4 \\
\hline & pneumoni & 9 & & & & & & & & & & \\
\hline & $a e$ & & & & & & & & & & & \\
\hline 99 & $K$ & qnrB1 & $>25$ & 1.5 & 6 & $\mathrm{~N} / \mathrm{D}$ & 2 & D87 & - & & SHV-28 & B5 \\
\hline & pneumoni & 9 & 6 & & & & & G & & & & \\
\hline & $a e$ & & & & & & & & & & & \\
\hline 107 & $K$ & qnrB1 & $>25$ & 1.5 & 4 & $\mathrm{~N} / \mathrm{D}$ & 1.5 & D87 & - & $x$ & & B2 \\
\hline & pneumoni & & 6 & & & & & G & & & & \\
\hline & $a e$ &  & & & & & & & & & & \\
\hline 109 & $K$ & $q n r B 1$ & $>25$ & 1 & 4 & $\mathrm{~N} / \mathrm{D}$ & 1.5 & D87 & - & $x$ & & B2 \\
\hline & pneumoni & 9 & 6 & & & & & G & & & & \\
\hline & $a e$ & & & & & & & & & & & \\
\hline
\end{tabular}




\begin{tabular}{|c|c|c|c|c|c|c|c|c|c|c|c|c|c|}
\hline 110 & $\begin{array}{l}\text { K. } \\
\text { pneumoni } \\
\text { ae }\end{array}$ & $\begin{array}{l}\text { qnrB1 } \\
9\end{array}$ & & $\begin{array}{c}>25 \\
6\end{array}$ & 0.75 & 3 & $\mathrm{~N} / \mathrm{D}$ & 1.5 & $\begin{array}{c}D 87 \\
G\end{array}$ & - & $X$ & TEM-150 & B1 \\
\hline 111 & $\begin{array}{l}\text { K. } \\
\text { pneumoni } \\
\text { ae }\end{array}$ & $\begin{array}{l}\text { qnrB1 } \\
9\end{array}$ & $\begin{array}{c}\operatorname{aac}\left(6^{\prime}\right) \\
-/ b\end{array}$ & $\begin{array}{c}>25 \\
6\end{array}$ & 1.5 & 4 & $\mathrm{~N} / \mathrm{D}$ & 2 & $\begin{array}{c}\mathrm{D} 87 \\
\mathrm{G}\end{array}$ & - & $x$ & $\begin{array}{l}\text { TEM-1 + } \\
\text { SHV-12 }\end{array}$ & B2 \\
\hline $111 \mathrm{~T}$ & $\begin{array}{l}\text { E. coli } \\
\text { TOP10 }\end{array}$ & $\begin{array}{l}\text { qnrB1 } \\
9\end{array}$ & & 128 & $\begin{array}{c}0.02 \\
3\end{array}$ & $\mathrm{~N} / \mathrm{D}$ & $\mathrm{N} / \mathrm{D}$ & $\mathrm{N} / \mathrm{D}$ & - & - & & & \\
\hline 112 & $\begin{array}{l}\text { K. } \\
\text { pneumoni } \\
\text { ae }\end{array}$ & $\begin{array}{l}\text { qnrB1 } \\
9\end{array}$ & & $\begin{array}{c}>25 \\
6\end{array}$ & 1 & 4 & $\mathrm{~N} / \mathrm{D}$ & 1.5 & $\begin{array}{c}\mathrm{D} 87 \\
\mathrm{G}\end{array}$ & - & $x$ & & B1 \\
\hline 114 & E. coli & qnrS1 & & 16 & 0.5 & 2 & $\mathrm{~N} / \mathrm{D}$ & 0.75 & - & - & $x$ & $\begin{array}{l}\text { TEM-150 } \\
+ \text { SHV- } \\
12+ \\
\text { CTX-M- } \\
1\end{array}$ & S3 \\
\hline 129 & $\begin{array}{l}\text { K. } \\
\text { pneumoni } \\
\text { ae }\end{array}$ & $\begin{array}{c}q n r B 1 \\
9\end{array}$ & & $\begin{array}{c}>25 \\
6\end{array}$ & 12 & $\geq 8$ & 32 & $\geq 8$ & $\begin{array}{c}D 87 \\
G\end{array}$ & - & $x$ & $\begin{array}{l}\text { TEM-150 } \\
+ \text { SHV- } \\
12\end{array}$ & B1 \\
\hline 132 & E. coli & $\begin{array}{l}\text { qnrB1 } \\
9\end{array}$ & & 16 & 0.32 & 1.5 & 0.38 & 0.5 & - & - & & & B6 \\
\hline $132 \mathrm{~T}$ & $\begin{array}{l}\text { E. coli } \\
\text { TOP10 }\end{array}$ & $\begin{array}{l}\text { qnrB1 } \\
9\end{array}$ & & 16 & 0.16 & $\mathrm{~N} / \mathrm{D}$ & 0.23 & $\mathrm{~N} / \mathrm{D}$ & - & - & & & \\
\hline
\end{tabular}




\begin{tabular}{|c|c|c|c|c|c|c|c|c|c|c|c|c|c|}
\hline $132 \mathrm{C}$ & $\begin{array}{l}\text { E. coli } \\
\mathrm{J}_{5} 3^{\mathrm{AzKanNa}} \\
\mathrm{R}\end{array}$ & $\begin{array}{l}\text { qnrB1 } \\
9\end{array}$ & & 16 & 0.32 & $\mathrm{~N} / \mathrm{D}$ & 0.32 & $\mathrm{~N} / \mathrm{D}$ & - & - & & & \\
\hline 137 & $\begin{array}{l}\text { K. } \\
\text { pneumoni } \\
\text { ae }\end{array}$ & $\begin{array}{l}\text { qnrB1 } \\
9\end{array}$ & $\begin{array}{l}\operatorname{aac}\left(6^{\prime}\right) \\
-1 b\end{array}$ & $\begin{array}{c}>25 \\
6\end{array}$ & 1 & 4 & 1.5 & 1.5 & $\begin{array}{c}\mathrm{D} 87 \\
\mathrm{G}\end{array}$ & - & $x$ & TEM-1 & B2 \\
\hline 138 & $\begin{array}{l}\text { K. } \\
\text { pneumoni } \\
\text { ae }\end{array}$ & $\begin{array}{l}\text { qnrB1 } \\
9\end{array}$ & & $\begin{array}{c}>25 \\
6\end{array}$ & 1.5 & 6 & 1.5 & 2 & $\begin{array}{c}\mathrm{D} 87 \\
\mathrm{G}\end{array}$ & - & $x$ & $\begin{array}{l}\text { TEM-150 } \\
+ \text { SHV- } \\
12\end{array}$ & B1 \\
\hline 143 & $\begin{array}{l}\text { K. } \\
\text { pneumoni } \\
\text { ae }\end{array}$ & $\begin{array}{l}\text { qnrB1 } \\
9\end{array}$ & $\begin{array}{c}\operatorname{aac}\left(6^{\prime}\right) \\
-/ b\end{array}$ & $\begin{array}{c}>25 \\
6\end{array}$ & 1.5 & 4 & 1.5 & 1.5 & $\begin{array}{c}\mathrm{D} 87 \\
\mathrm{G}\end{array}$ & - & & $\begin{array}{l}\text { TEM-150 } \\
+ \text { SHV- } \\
12\end{array}$ & B2 \\
\hline 144 & $\begin{array}{l}\text { K. } \\
\text { pneumoni } \\
\text { ae }\end{array}$ & $\begin{array}{l}\text { qnrB1 } \\
9\end{array}$ & $\begin{array}{c}\operatorname{aac}\left(6^{\prime}\right) \\
-1 b\end{array}$ & $\begin{array}{c}>25 \\
6\end{array}$ & 1.5 & 6 & 1.5 & 1.5 & $\begin{array}{c}D 87 \\
G\end{array}$ & - & $X$ & TEM-150 & B2 \\
\hline 146 & $\begin{array}{l}\text { K. } \\
\text { pneumoni } \\
\text { ae }\end{array}$ & $\begin{array}{l}\text { qnrB1 } \\
9\end{array}$ & & $\begin{array}{c}>25 \\
6\end{array}$ & 1 & 4 & 1.5 & 2 & $\begin{array}{c}\mathrm{D} 87 \\
\mathrm{G}\end{array}$ & - & $x$ & $\begin{array}{l}\text { TEM-150 } \\
+ \text { SHV- } \\
12\end{array}$ & B1 \\
\hline $146 \mathrm{~T}$ & $\begin{array}{l}\text { E. coli } \\
\text { TOP10 }\end{array}$ & $\begin{array}{l}\text { qnrB1 } \\
9\end{array}$ & & 128 & $\begin{array}{c}0.02 \\
3\end{array}$ & $\mathrm{~N} / \mathrm{D}$ & $\mathrm{N} / \mathrm{D}$ & $\mathrm{N} / \mathrm{D}$ & - & - & & & \\
\hline 147 & $\begin{array}{l}\text { K. } \\
\text { pneumoni } \\
\text { ae }\end{array}$ & $\begin{array}{l}\text { qnrB1 } \\
9\end{array}$ & & $\begin{array}{c}>25 \\
6\end{array}$ & 1 & 6 & 2 & 2 & $\begin{array}{c}\mathrm{D} 87 \\
\mathrm{G}\end{array}$ & - & $x$ & TEM-1 & B1 \\
\hline
\end{tabular}




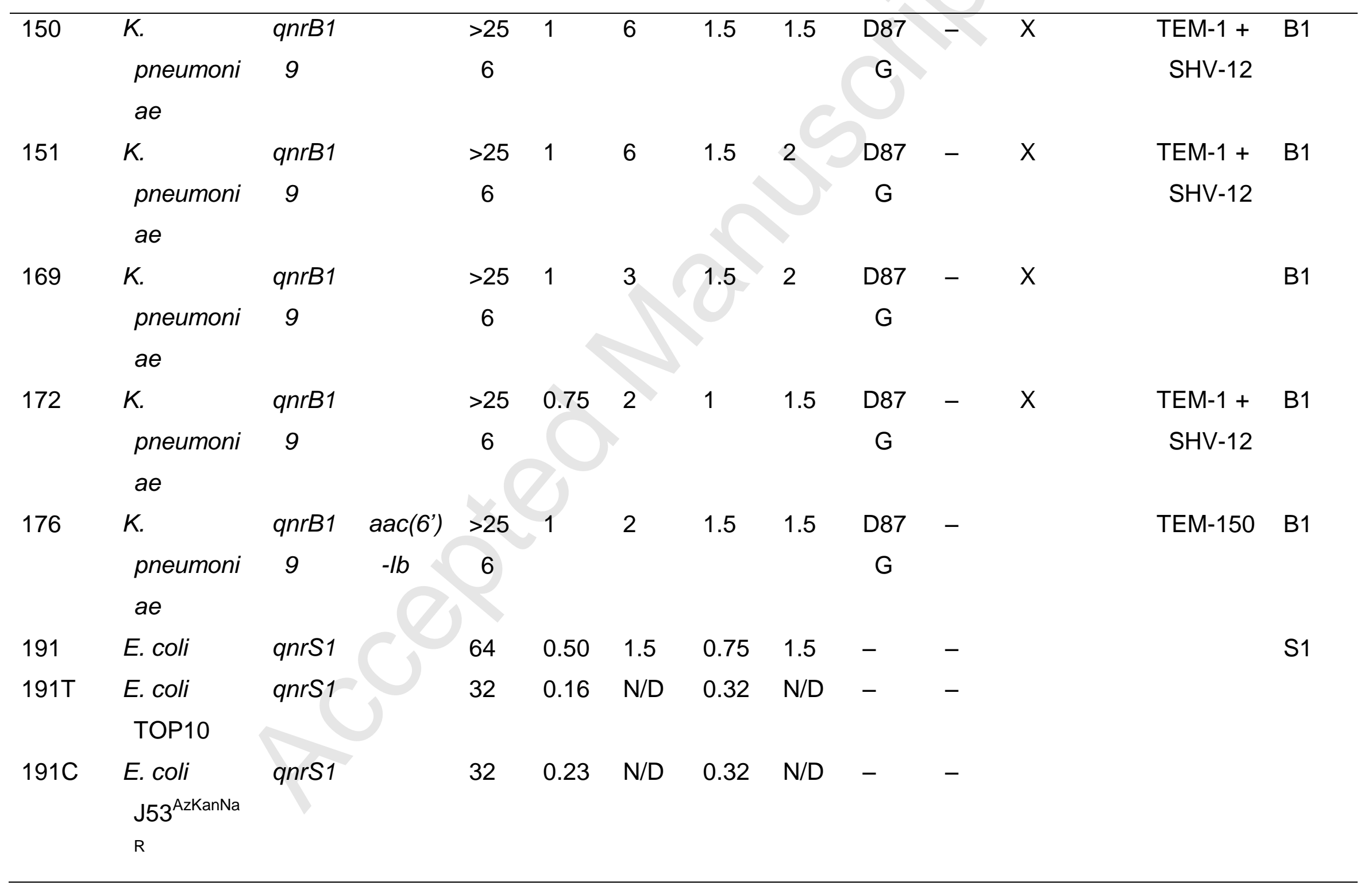




\begin{tabular}{|c|c|c|c|c|c|c|c|c|c|c|c|c|}
\hline 196 & $\begin{array}{l}\text { K. } \\
\text { pneumoni } \\
\text { ae }\end{array}$ & $\begin{array}{l}\text { qnrB1 } \\
9\end{array}$ & $\begin{array}{c}>25 \\
6\end{array}$ & 1 & 3 & 1.5 & 1.5 & $\begin{array}{c}D 87 \\
G\end{array}$ & - & $X$ & TEM-1 & B1 \\
\hline 204 & $\begin{array}{l}\text { K. } \\
\text { pneumoni } \\
\text { ae }\end{array}$ & $\begin{array}{l}q n r B 1 \\
9\end{array}$ & 32 & 0.75 & 4 & 1.5 & 2 & - & - & & SHV-12 & B4 \\
\hline 229 & $\begin{array}{l}\text { K. } \\
\text { pneumoni } \\
\text { ae }\end{array}$ & $\begin{array}{l}q n r B 1 \\
9\end{array}$ & 32 & 0.5 & 2 & 1 & 1.5 & - & - & & TEM-1 & B4 \\
\hline 282 & E. coli & qnrS1 & 16 & 0.5 & 1.5 & 0.75 & 0.5 & - & - & & TEM-1 & $\mathrm{S} 2$ \\
\hline $282 \mathrm{~T}$ & $\begin{array}{l}\text { E. coli } \\
\text { TOP10 }\end{array}$ & qnrS1 & 16 & 0.23 & $N / D$ & 0.32 & $N / D$ & - & - & & & \\
\hline 290 & $\begin{array}{l}\text { K. } \\
\text { pneumoni } \\
\text { ae }\end{array}$ & $\begin{array}{l}q n r B 1 \\
9\end{array}$ & $\begin{array}{c}>25 \\
6\end{array}$ & 2 & 6 & 3 & 3 & $\begin{array}{c}\mathrm{D} 87 \\
\mathrm{G}\end{array}$ & - & $x$ & $\begin{array}{l}\text { TEM-150 } \\
+ \text { SHV- } \\
12\end{array}$ & B3 \\
\hline 307 & $\begin{array}{l}\text { K. } \\
\text { pneumoni } \\
\text { ae }\end{array}$ & $\begin{array}{c}q n r B 1 \\
9\end{array}$ & $\begin{array}{c}>25 \\
6\end{array}$ & 1 & 3 & 1.5 & 2 & $\begin{array}{c}\mathrm{D} 87 \\
\mathrm{G}\end{array}$ & - & $x$ & & B1 \\
\hline 328 & $\begin{array}{l}\text { K. } \\
\text { pneumoni } \\
\text { ae }\end{array}$ & $\begin{array}{l}q n r B 1 \\
9\end{array}$ & $\begin{array}{c}>25 \\
6\end{array}$ & 2 & 12 & 3 & 3 & $\begin{array}{c}\mathrm{D} 87 \\
\mathrm{G}\end{array}$ & - & $x$ & $\begin{array}{l}\text { TEM-150 } \\
+ \text { SHV- } \\
12\end{array}$ & B1 \\
\hline
\end{tabular}




\begin{tabular}{|c|c|c|c|c|c|c|c|c|c|c|c|c|}
\hline 370 & $\begin{array}{l}\text { K. } \\
\text { pneumoni } \\
\text { ae }\end{array}$ & $\begin{array}{l}\text { qnrB1 } \\
9\end{array}$ & $\begin{array}{c}>25 \\
6\end{array}$ & 1.5 & 6 & 2 & 3 & $\begin{array}{c}\mathrm{D} 87 \\
\mathrm{G}\end{array}$ & - & $X$ & $\begin{array}{l}\text { TEM-1 + } \\
\text { SHV-12 }\end{array}$ & B1 \\
\hline 374 & $\begin{array}{l}\text { K. } \\
\text { pneumoni } \\
\text { ae }\end{array}$ & $\begin{array}{l}\text { qnrB1 } \\
9\end{array}$ & $\begin{array}{c}>25 \\
6\end{array}$ & 1.5 & 4 & 1.5 & 2 & $\begin{array}{c}\mathrm{D} 87 \\
\mathrm{G}\end{array}$ & - & $x$ & SHV-12 & B1 \\
\hline 450 & $\begin{array}{l}\text { K. } \\
\text { pneumoni } \\
\text { ae }\end{array}$ & $\begin{array}{l}\text { qnrB1 } \\
9\end{array}$ & $\begin{array}{c}>25 \\
6\end{array}$ & 0.25 & 0.5 & 0.38 & 0.38 & $\begin{array}{c}\mathrm{D} 87 \\
\mathrm{G}\end{array}$ & - & & SHV-28 & B1 \\
\hline & $\begin{array}{l}\text { E. coli } \\
\text { TOP10 }\end{array}$ & & 1 & $\begin{array}{c}0.00 \\
2\end{array}$ & $\begin{array}{c}0.01 \\
6\end{array}$ & $\begin{array}{c}0.00 \\
4\end{array}$ & $\begin{array}{c}0.00 \\
6\end{array}$ & - & - & & & \\
\hline & $\mathrm{J} 53^{\text {AzKanR }}$ & & 3 & $\begin{array}{c}0.01 \\
6\end{array}$ & $\begin{array}{c}0.04 \\
7\end{array}$ & $\begin{array}{c}0.04 \\
7\end{array}$ & $\begin{array}{c}0.02 \\
3\end{array}$ & - & - & & & \\
\hline
\end{tabular}

MIC, minimum inhibitory concentration; NA, nalidixic acid; CIP, ciprofloxacin; OFX, ofloxacin; LVF, levofloxacin; MXF, moxifloxacin; ESBL, extended-spectrum $\beta$-lactamase; ERIC-PCR, 'enterobacterial repetitive intergenic consensus' polymerase chain reaction; $T$, transformant strain; $C$, transconjugant strain; N/D, not determined.

${ }^{a}$ ESBL phenotypic determination ( $\mathrm{X}=\mathrm{ESBL}-$ producer) and genotypic determination (ESBL type). 


\section{Table 2}

Susceptibility (no. of isolates) of qnr-positive isolates to quinolone drugs according to Clinical and Laboratory Standards Institute $(\mathrm{CLSI})^{\mathrm{a}}$ and European Committee on Antimicrobial Susceptibility Testing (EUCAST) ${ }^{\mathrm{b}}$ breakpoints

\begin{tabular}{lllllllllll}
\hline \multirow{2}{*}{$\begin{array}{lllllllll}\text { Susceptibili } \\
\text { ty }\end{array}$} & NA & \multicolumn{3}{c}{ CIP } & \multicolumn{3}{l}{ OFX } & \multicolumn{2}{l}{ LVF } & MXF \\
\cline { 2 - 11 } & CL & EUCAS & CLS & EUCAS & CLS & EUCAS & CLS & EUCAS & CLS & EUCAS \\
& SI & T & I & T & I & T & I & T & I & T \\
\hline $\mathrm{R}$ & 31 & 33 & 3 & 15 & 5 & 37 & 3 & 5 & 3 & 33 \\
$\mathrm{I}$ & 2 & 0 & 12 & 16 & 24 & 2 & 2 & 17 & 3 & 1 \\
$\mathrm{~S}$ & 7 & 7 & 25 & 9 & 11 & 1 & 23 & 6 & 34 & 6 \\
\hline
\end{tabular}

NA, nalidixic acid; CIP, ciprofloxacin; OFX, ofloxacin; LVF, levofloxacin; MXF, moxifloxacin; R, resistant; I, intermediate; S, susceptible.

${ }^{a}$ Resistance ranges according to CLSI breakpoints ( $\mathrm{mg} / \mathrm{L}$ ): nalidixic acid, $S \leq 16, R \geq 32$;

ciprofloxacin, $S \leq 1, I=2, R \geq 4$; and ofloxacin, levofloxacin and moxifloxacin, $S \leq 2, I=4, R \geq$ 8.

${ }^{\mathrm{b}}$ Resistance ranges according to EUCAST breakpoints (mg/L): nalidixic acid, $\mathrm{S} \leq 16, \mathrm{R}>16$; ciprofloxacin, ofloxacin and moxifloxacin, $S \leq 0.5, R>1$; and levofloxacin, $S \leq 1, R>2$. 


$$
\begin{aligned}
& \begin{array}{llllllll}
S & S & S & B & B & B & B & q n r
\end{array}
\end{aligned}
$$

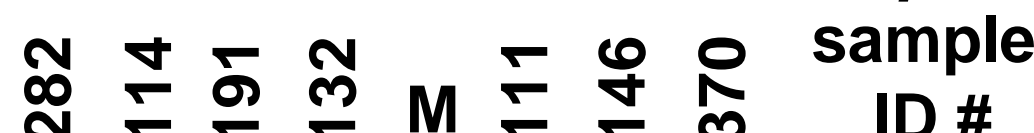

$$
\begin{aligned}
& \text { N }
\end{aligned}
$$

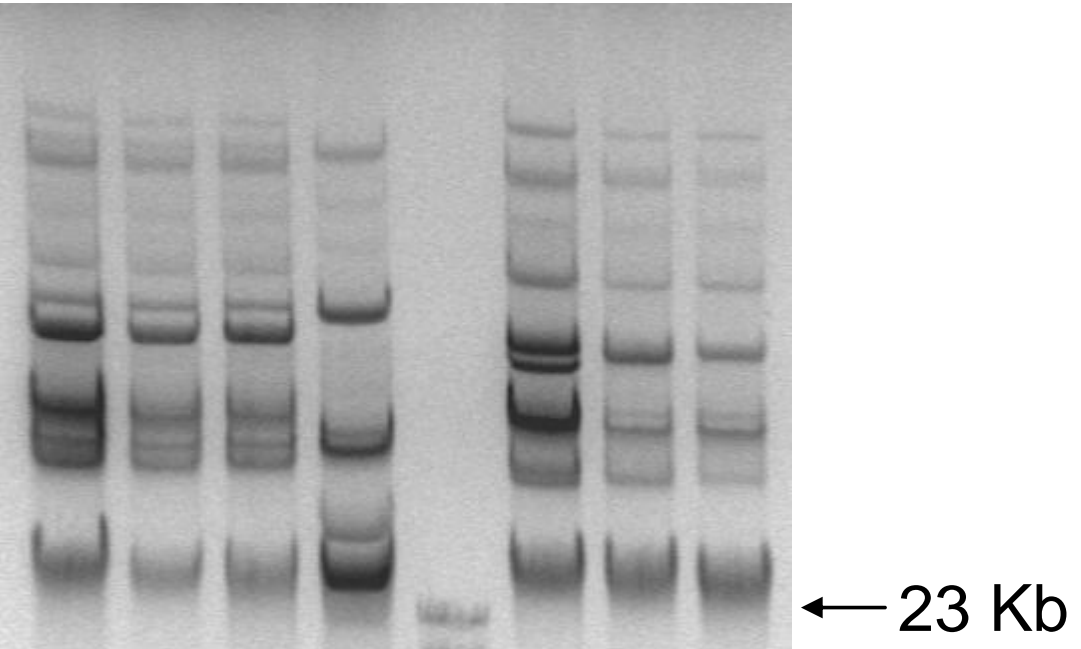




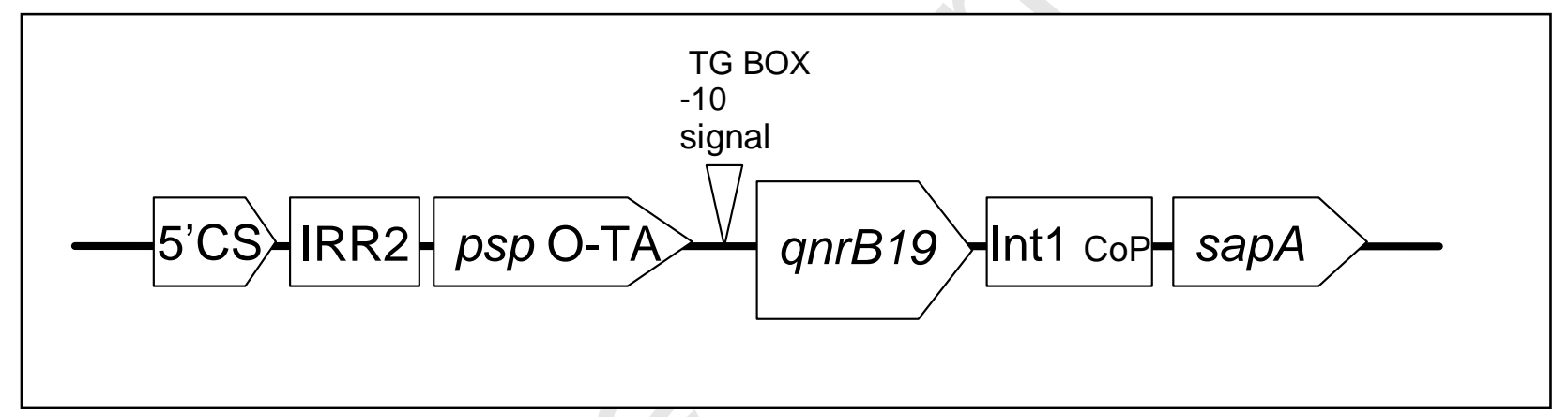

